\title{
Wild European dewberry, Rubus caesius L. (fam. Rosaceae), in Sweden: from traditional regional consumption to exotic dessert at the Nobel Prize banquet
}

Ingvar Svanberg ${ }^{*}$ and Sabira Ståhlberg

\begin{abstract}
European dewberry, Rubus caesius L. (fam. Rosaceae), played an insignificant role as local food in Sweden before the twentieth century. It is known as salmbär'Solomon berries' in the severely endangered regional language Gutnish, spoken in the Baltic Sea islands Gotland and Fårö. From a largely ignored food product with limited regional use, European dewberry has made a quick culinary journey to the top. Today dewberry jam is popular throughout Sweden, and it is usually served during festive occasions with a local Gotland specialty, oven-baked saffron pancake. This dish symbolizes the food culture of the island, and the demand for dewberries has increased together with the development of local tourism, the search for exciting heritage food, and the regional identity building efforts. Berries are harvested by foreign seasonal workers for commercial purposes, and dewberry jam is now also available in specialized shops in mainland Sweden. Inspired by the New Nordic Cuisine movement in the 2000s, several chefs, especially from fine dining restaurants, have created innovative dishes with dewberry jam; it was even served at the Nobel Prize banquet in December 2014. This article discusses the change of status and ascent of a locally used berry to a fashionable dessert in Sweden.
\end{abstract}

Keywords: Ethnobiology, Ecosystem services, Food culture, Forest berries, Gathering activities, Local knowledge, Nordic cuisine, Wild food

\section{Introduction}

Sweden's vast forests provide a multitude of important ecosystem services, such as biodiversity, clean water, timber, food, and possibilities for recreation [1]. Gathering and consuming wild forest berries and mushrooms are popular activities among the population [2]. The right of public access to the landscape (allemansrätten) permits everyone to roam freely on state and private land outside inhabited areas, and to pick berries, mushrooms, twigs, branches, and wildflowers for their own

${ }^{*}$ Correspondence: ingvar.svanberg@ires.uu.se

Institute for Russian and Eurasian Studies, Uppsala University, Box 514, 75120 Uppsala, Sweden use in the forest, but it does not cover hunting or fishing in rivers and lakes. Along the coasts, however, fishing is permitted. Berry picking for commercial purposes is also allowed, as long as it does not cause damage to the area or any inconvenience for the owner. In the past few years, land owners have tried to initiate law changes related to commercial use, but specialized companies still have the unique opportunity to harvest berries on a large scale both on private and state lands. This public right is crucial also for the general interest of the inhabitants in using non-timber forest resources $[3,4]$.

To understand the contemporary utilization of individual wild food products, ethnobiologists must study the importance of such products both from the historical 
and present perspectives [5]. Macro-level factors include cultural, economic, educational, environmental, political and social transformations, changes in living conditions and societies over time, and also the significance of activity contexts between biota and human beings [6]. Wild edible plant use is also modified; the degree of individual or family self-sufficiency decreases with urbanization, industrialization, and globalization. Wild berries, a few centuries ago an overlooked forest product, are now considered sustainable, healthy and 'clean' food, and the consumption is increasing rapidly in Sweden [7].

This process of transformation can be clearly observed in Northern Europe. The traditional economic uses of many wild plants have disappeared with the social and economic changes during the twentieth century [8]. However, the consumption of uncultivated plants, including berries, was rather small among independent peasants in pre-industrial Sweden [3, 9]. The situation was somewhat different for crofters, Sámi nomads, and poor marginalized groups, and also in Sweden's eastern province of Finland, where forest products were used more frequently in the diet. For the Swedish peasants, fish was much more important than wild plants [10]. Only a few sweet forest berries, which did not require extra sugar supply, would be added to bread [11]. The economic importance of wild plants, especially forest berries, gained momentum only with larger sugar availability in the nineteenth century, modern ways of cooking and food preparation, changed taste preferences, and transmutations in the food chain $[3,12]$.

The dewberry is a typical example of an edible but sourtasting berry rarely used as food until fairly recently [3, 13]. Yet already in 1658, Olaus Rudbeck the Elder (16301702) noted in mainland Sweden that the berries could be used as food and medicine, but he provided no further details about how, where and by whom [14]. In 1792, the early economic writer Johan Fischerström (1735-1796) recommended dewberry for improvement in wine [15]. A botanical handbook from the early 1800 s stated that the berries could be eaten as jam or fresh [16]. Children probably picked dewberries and ate them on the spot as a snack, as they did with many other edible wild berries, but otherwise it was of insignificant food value [3]. Only from the small island Blidö in the Stockholm archipelago, records from the 1930s state that adolescents occasionally picked them [17]. In 2008, the Programme for Diversity of Cultivated Plants (POM), after a country-wide inventory of old cultivated plants in Swedish gardens, reported a stand of dewberry planted along a wall surrounding the entrance of an old villa in the province of Uppland north of Stockholm. The bushes were ornamental and also supplied the household with fresh berries [18] (Fig. 1).
In the modern international and national foodscapes, dishes marketed as regional specialties occupy an important place. Small amounts of dewberry jam were consumed locally in the island of Gotland during the past century, yet only within a few decades the berry has been developed into a commercially viable product. Dewberry jam might therefore qualify as a locally consumed ethnic food receiving increasing national and global attention. Its status is rising, and popularity has been stimulated by the development of the local tourist business, but also by the culinary movement called New Nordic Cuisine. This fashionable initiative in the early 2000s challenges eminent chefs to create dishes based on locally available raw products [19]. Concepts such as locally produced ingredients and terroir are important factors for branding food in this regionally and nationally based context [20]. In the new Nordic way of culinary thinking, the previously insignificant dewberry has become an attractive component, both in regional and high-level circles in Swedish cuisine. Oven-made saffron pancakes served with dewberry jam are now a specialty strongly connected with the picturesque and romantic island of Gotland (Fig. 2).

Creative food artisans have also developed additional dishes and products based on dewberry intended for the market. These products are often sold as regional merchandise in Gotland tourist stores. Although wild forest berries are common in the Swedish diet nowadays [21, $22]$, the harvesting, use, and marketing of the dewberry remains unique.

\section{Botany and ecology}

The European dewberry plant, Rubus caesius L., is a small shrub with biennial stems, which die after fruiting in their second year. The plant sends out long runners, rooting at the tip to form new plants. The alternate leaves are hairy both on the surface and underneath. The edible fruit is a glaucous, bluish-black aggregate of a few drupelets. The few large and blue berries ripen usually in August in the north of Europe [23].

This close relative to bramble, Rubus fruticosus L., and raspberry, Rubus idaeus L., is common on the island of Gotland in the Baltic Sea, as well as in the southern province of Skåne. It also thrives in the lime-rich soil on the shores and in the archipelago along the Baltic Sea coast as far north as Uppland (around the $60^{\text {th }}$ parallel north). The dewberry is especially common in the southwestern part of Gotland, but its frequency decreases eastward toward the open sea, where it is still rather common. Dewberries can be found less frequently in the northern part of the island [24]. In Finland, dewberry bushes grow in the coastal Swedish-speaking regions, the Åland Islands, and locally along the southern and southwestern coasts [25] (Fig. 3). 


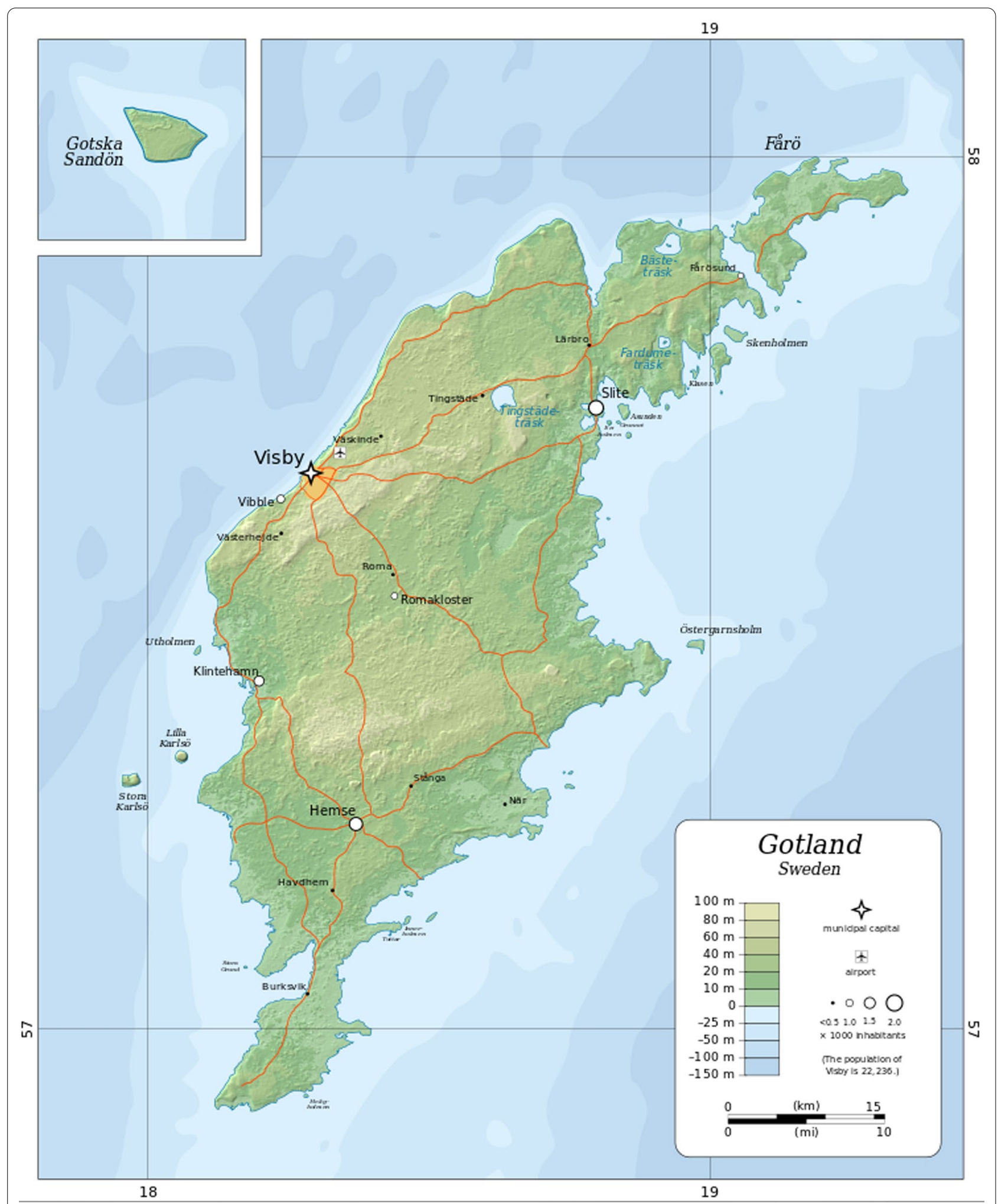

Fig. 1 (Map 1) Topographical map of Gotland. This wind-blown island is a popular summer destination for Swedish and foreign tourists. Gotland and the southernmost province of Skåne are the only areas in Sweden, where the European dewberry grows in large amounts, although it can be found up to the $60^{\text {th }}$ north parallel. Dewberry has in the recent decades, however, become specifically associated with Gotland (Map: Oona Räisänen, Creative Commons) 


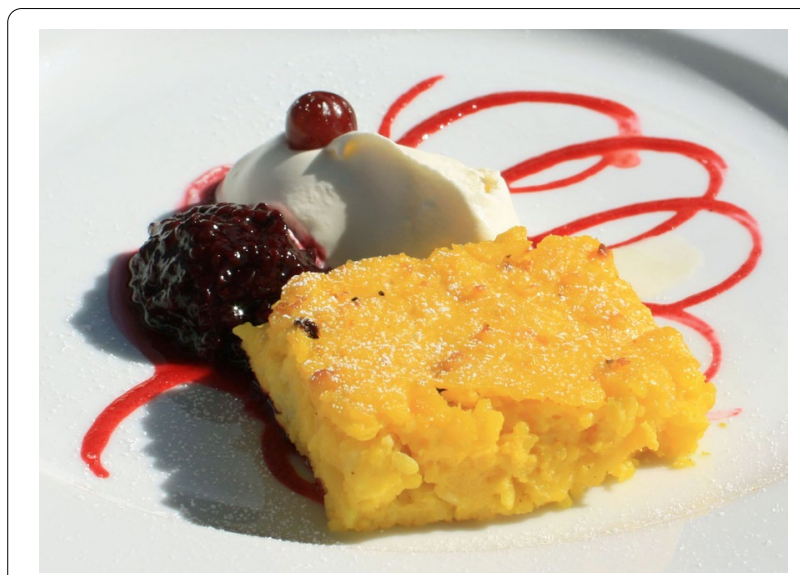

Fig. 2 Oven-made saffron pancake is a century-old traditional dessert from Gotland and considered a typical provincial dish connected with this island located in the Baltic Sea. Saffron pancake was earlier served only in connection with weddings and other festivities. This 'cake' is made of pudding rice, cream, milk, sugar, egg, chopped almonds, and flavored with saffron, which gives its typical yellow color. Nowadays, saffron pancake is a common dish especially in local restaurants and cafes catering for the 1.5 million tourists visiting Gotland every year. The pancake is usually served lukewarm with dewberry jam and whipped cream, along with coffee (Photo: Wikimedia Commons)

\section{Local names}

Although dewberry is presently called blåhallon 'blue raspberry' in Swedish botanical handbooks (since 1659) $[23,26,27]$, the edible fruits are nowadays better known under the Gutnish name salmbär, in Fårö pronounced salmunabär. The name should be interpreted as salomonbär 'Solomon berries' [28-30]. The logic behind it is uncertain. Certainly, King Solomon carried a reputation for great wealth, wisdom, and righteousness. According to the Bible, he also possessed a great knowledge of plants (1 King 4:33). The name salmbär has been recorded all over Gotland, including Fårö, located just off the north cape of the island [31-34]. The use of biblical references in phytonyms, including King Solomon, is quite common in Gutnish and several Swedish dialects [35]. Carl Linnaeus' spelling psalmbär indicates that for some reason he interpreted the first element as 'psalm, hymn', and not a short form for Solomon [28].

In Flora svecica (1745 and 1755), Linnaeus noted several local and provincial names for the dewberry in Sweden: kalvhjortron 'calf cloudberry' (Uppland); käringbär 'old woman berry' (Västergötland); björnhallon 'bear raspberry' (Östergötland); björnbär 'bear berry' (Småland); skottluva 'bullet cap' (Bohuslän); and noted for the first time by Linnaeus in 1749, käringtarmar 'old woman intestines', in the southernmost province of Skåne [36]. In Uppland, the berry was also called åkerhallon 'field raspberry' $[37,38]$.

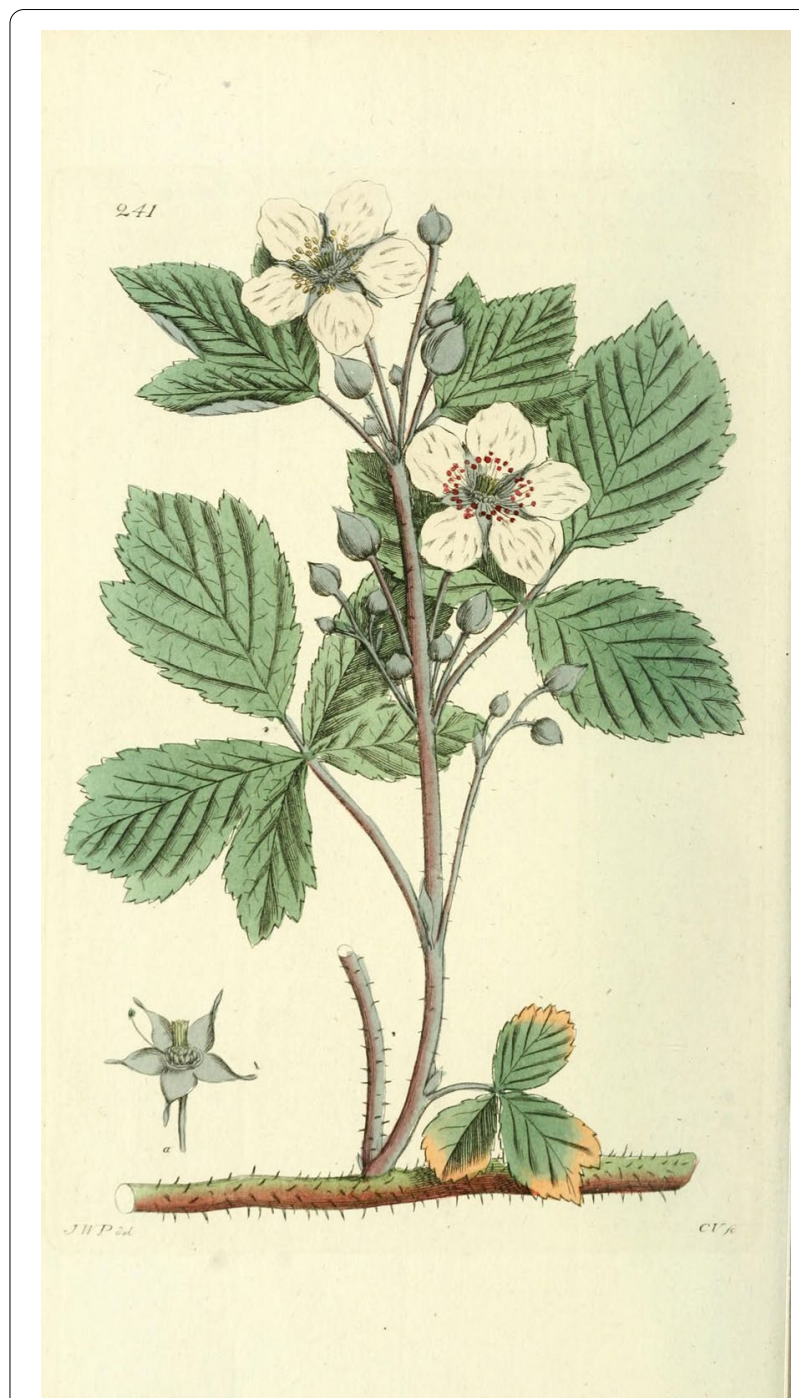

Fig. 3 An early nineteenth-century illustration of Rubus caesius, showing the flowers, berry, root, and leaves. European dewberry is a small shrub with hairy leaves and biennial stems, which die after fruiting in their second year. The plant sends out long runners, which root at the tops to create new plants. In this illustration, the dewberry looks very dark blue, almost black, but the illustrator has with great fidelity to the original captivated different parts of this rarely used plant before the arrival of the twentieth century and greater availability of sugar (Source: C. Quensel \& J.W. Palmstruch Svensk botanik vol. 4, 1805)

There are also other names recorded from Sweden [39] and Finland, among them strandhallon 'beach raspberry' in the Åland Islands [40] and strandhallon and svarthallon 'black raspberry' in the Swedishspeaking parts of southern Finland. These phytonyms are hardly used anymore [41]. The Finnish-speakers along the southern coast call it sinivatukka 'blue raspberry,' first recorded in 1860 and probably a calque of 
the Swedish name blåhallon [42]. The now linguistically assimilated, earlier Swedish-speakers on Dagö (Estonian Hiiumaa) in Estonia [43] called the berries åkerbär 'field berry' [44].

\section{Aim, sources and methods}

The goals of this study are to describe how dewberry developed from a local and insignificant wild plant product to a raw product in high demand at the upper end of national cuisine and how this process connects with the expansion of the local tourism business in Sweden and the creation of a new regional cuisine. Ethnographic archive materials, local historical works, newspapers, glossaries, and studies of contemporary gastronomy and tourism development are used [6].

The results contribute to expand our understanding of how knowledge of local wild plants is transmitted and transformed from traditional food systems into modern cuisine. This article is also a contribution to the discussion about the future of local wild food products in Sweden, especially for those promoting local small businesses and sustainable quality food.

\section{Results}

\section{Historical observations and use}

The oldest known record of the Gutnish (Gotlandish) phytonym for dewberry, rendered as salmbärsört 'Solomon berry herb', is found in an old herbarium vivum from 1701. This collection of plants, compiled by the vicar Antonius Münchenberg (1680-1743), is today kept at the Swedish Natural History in Stockholm. It consists of several sheets with voucher specimens of wild and domesticated plants gathered in Gotland. A few specimens are also from Stora Karlsö, a small island off the west coast of Gotland, known for its rich bird life. The voucher specimens are glued on paper sheets, and each plant is accompanied by a short Latin diagnosis, probably written when the plant was added to the herbarium [45]. The diagnosis is followed by information about the habitat, flowering period, names in Latin, Swedish and German, and information about usage, usually quoted or directly copied from the Danish naturalist Simon Paulli's (1603-1680) Flora Danica (1648) [46] (Fig. 4).

In the herbarium, there are also some original records about the uses or virtues of plants, probably collected by Münchenberg. Several of these original records are of interest for ethnobiologists and linguists and deserve further examination, as there are

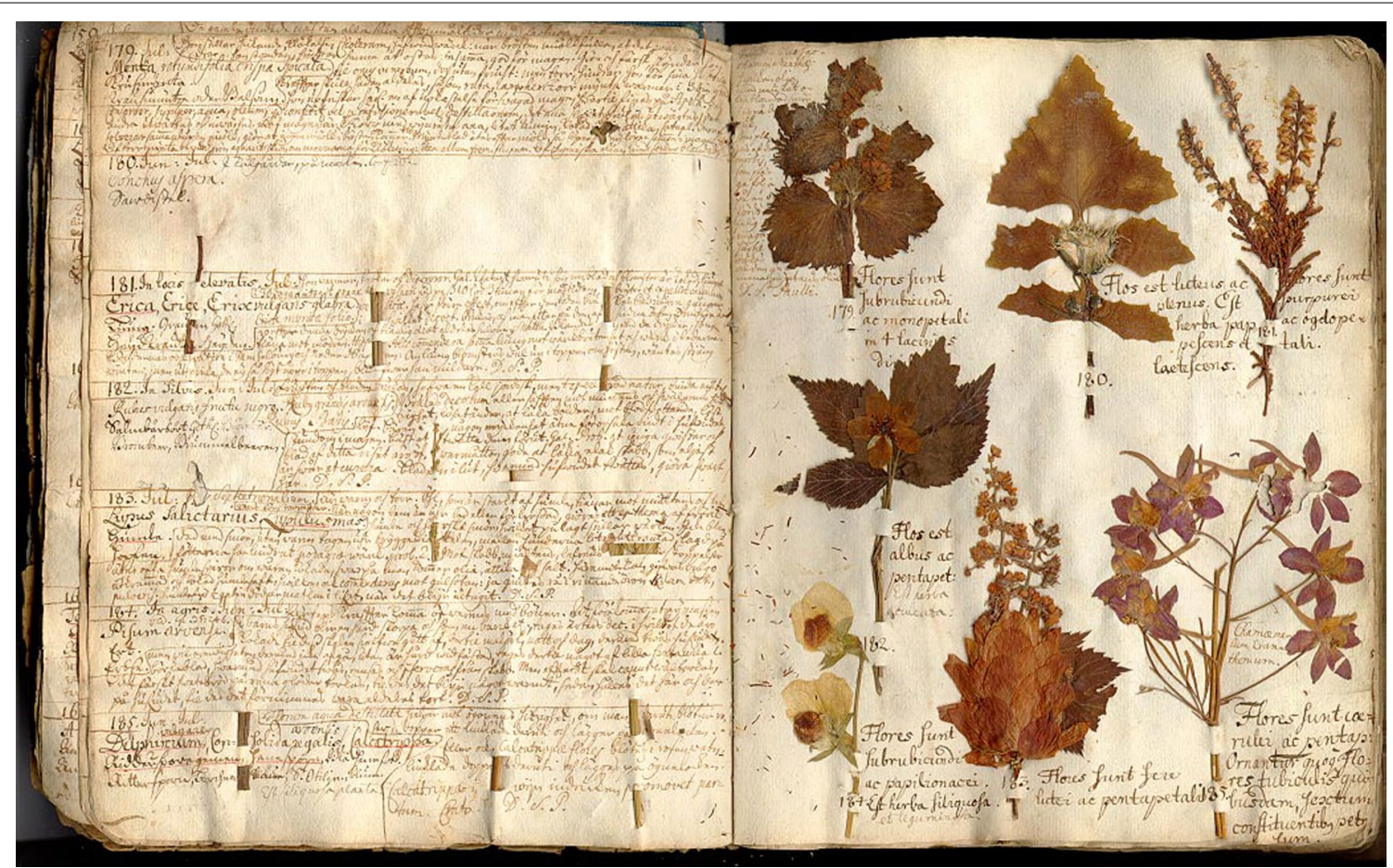

Fig. 4 A sheet from Antonius Münchenberg's handwritten herbarium vivum with a voucher specimen of Rubus caesius in the middle. This is the oldest dated collection of plants from Gotland. It contains besides illustrations also notes (diagnosis) about the uses and 'virtues' of various species. Most of the specimens in this collections were gathered in Hejde parish in the central part of the island during 1701 and 1702 . The herbarium further offers some old Guthnic phytonyms (Photo: Courtesy Swedish Natural History Museum, Stockholm) 
also names recorded in the Gutnish language [32]. Gutnish is the original Germanic language, different from Swedish, spoken in Gotland and the island of Fårö north of Gotland. UNESCO defines Gutnish as a definitely endangered language, spoken only by a few islanders at present [47].

Neither Münchenberg, nor the famous scholar Carl Linnaeus (1707-1778), who visited the islands Öland and Gotland in the summer of 1741, mentions dewberry as food. Linnaeus' mission was to record economic aspects (especially dye, edibility, and medicinal virtues) of wild plants. He found dewberries on both islands, but recorded no use of them. In När parish, southeastern Gotland, Linnaeus recorded merely the local Gutnish phytonym psalmbär 'psalm berry' for the taxon [48]. Although the fleshy berries were edible, they were hardly used by the peasants, or at least they did not play any remarkable role in the local diet. Dewberry had probably very little or no cultural significance in Gotland in this period; there are also no cultural references in the local pre-industrial lore. The only folkloric record found about the dewberry plant is from Garde parish in the southern part of Gotland: the long runners of the dewberry shrub were seen as a sign, predicting a long and cold winter [49]. The phytonym salmbär is seldom found in any toponyms, a fact ethnobiologists generally see as an important indication if a plant has had any economic importance [50]. The only known toponym is the homestead Salmstäder in Hejde parish, Gotland; it probably indicates a larger occurrence of salmbär in the neighborhood [27].

With modernization, a growing availability of sugar, and an expanding interest in wild forest berries as a food resource in the nineteenth century, also the dewberries became more important, especially on Gotland, where they grow abundantly in the landscape. Ethnographic records report that berries were gathered and made into jam and cordial in the early twentieth century [51]. A few decades later the berries were already used in many parts of the island and consumed as jam in the households [52]. Dewberry jam was usually served with oven-made pancakes flavored with saffron. This kind of pancakes was not prepared until the end of the nineteenth century, when rice entered the menu, and wood-burning iron stoves with a built-in oven became common in Sweden. The thick pancake is made of short-grain rice, mostly used for porridge. Nowadays, the pancake contains rice pudding, saffron, sugar, eggs, cream, vanilla sugar, and almonds. The ingredients are mixed and poured into a well-greased oven form; half an hour in the oven is enough before serving the dessert, which is similar to a sturdy cake, with coffee [53].

\section{Contemporary use}

Dewberry jam has increased its popularity in Gotland in the past decades, and it is chiefly, but not solely served with the luxurious saffron pancake today [54]. Although it was still rather rare in the mid-twentieth century, the dish is nowadays perceived as a typical regional symbol of Gotland cuisine, offered at weddings and other joyful events. The dish has also become hugely popular among tourists, and it figures frequently in the menus of local restaurants $[3,55]$. There are many recipes available on internet, too [56].

Dewberries are harvested today in late summer or early autumn; they must be completely ripe in order to get the right flavor for the jam, but still large amounts of sugar are needed to camouflage the sour taste. Picking the berries has become a popular pastime for many households on the island, but due to increasing demand, several tons are harvested each year for the local small-scale factories [53]. The first production facility was founded in the 1980s. The commercially harvested berries and products from them (chiefly jam) are mainly sold to the local restaurants (Fig. 5).

In 2008, four tons of berries were gathered on Gotland, and in 2012 one of the companies reported that it bought eight tons from local berry pickers. Still, the amount of berries does not meet the growing demand of the tourists and from shops on the mainland. Local needs and regional pride cause small producers to refuse to sell their jam to buyers on the mainland; they prefer to reserve it for local use, restaurants and tourist shops. In 2014, five commercial purchasers of dewberries were active in Gotland. Mainly Thai women are hired as seasonal pickers to bring in the harvest for the local companies. In 2015, 70 female Thai pickers gathered nearly 15 tons of berries. The amount of berries harvested annually depends on the availability; despite fluctuations, dewberry picking remains a regional economic factor $[55,57]$.

Regional images and promotion of specific local foods are crucial for the modern tourist industry. Tourism is seen as one of the two most important economic areas for the future development of Gotland; the other is the food industry. The tourist agencies focus on environmental aspects of sustainable tourism [58, 59], and the development of gastrotourism is part of this new trend. Gastrotourism is a niche within the global tourist business, and it attracts billions in revenue worldwide [55, 59-61].

A common phenomenon today is the expansion of local foods into new kinds of dishes or products. Gotland is no exception: the unique flavor of dewberry is used for several food products. Besides jam, there are locally made balsamic vinegar, chutney, cordial, ice cream, and marmalade. Liquor stores offer an aquavit, Gute 


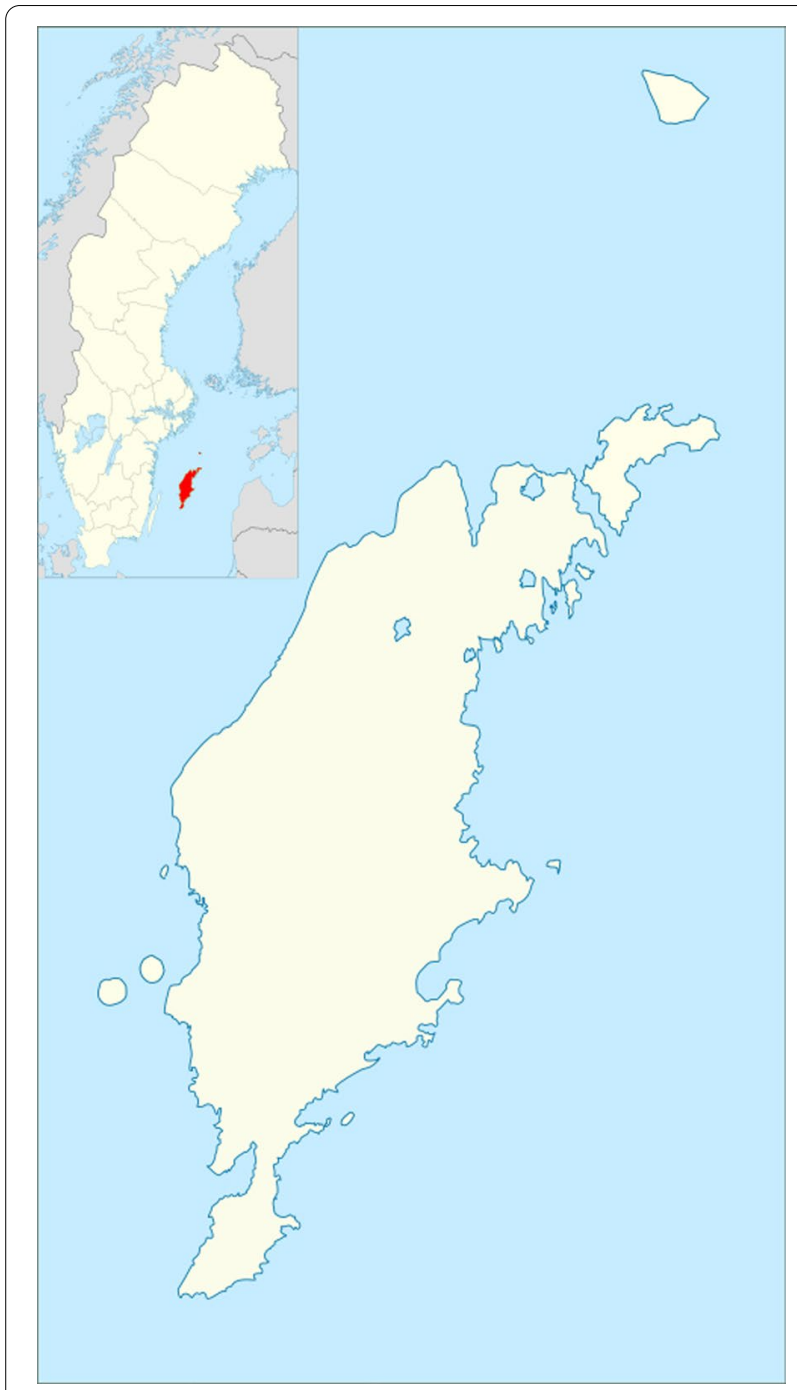

Fig. 5 (Map 2) Gotland is an island with approximately 58,000 inhabitants and more than a million tourists every summer. This picturesque, small, roughly leaf-shaped island is located in the Baltic Sea about $90 \mathrm{~km}$ east of the Swedish mainland. For several decades, Gotland has been a hugely popular tourist destination. Today gastrotourism is one of the fastest growing parts of the tourist business, but also the small traditional houses in the capital Visby attract visitors, as well as the natural sights, rocky shores, and beautiful meadows, which can be visited for instance on bicycle (Map: CC BY-SA 3.0 Published under the terms of GNU Free Documentation License)

Salmbärsbris, flavored with dewberries. An interesting recently invented tradition is the so-called Polhemsbakelsen, a pastry developed in Visby in 2008, containing vanilla cream, dewberry jam, and whipped cream. It is served in cafes on the name day of Christopher on March 15. This tart is named after the Swedish inventor and scientist Christopher Polhem, who was born on Gotland in 1661 (d. 1751) [62] (Fig. 6).

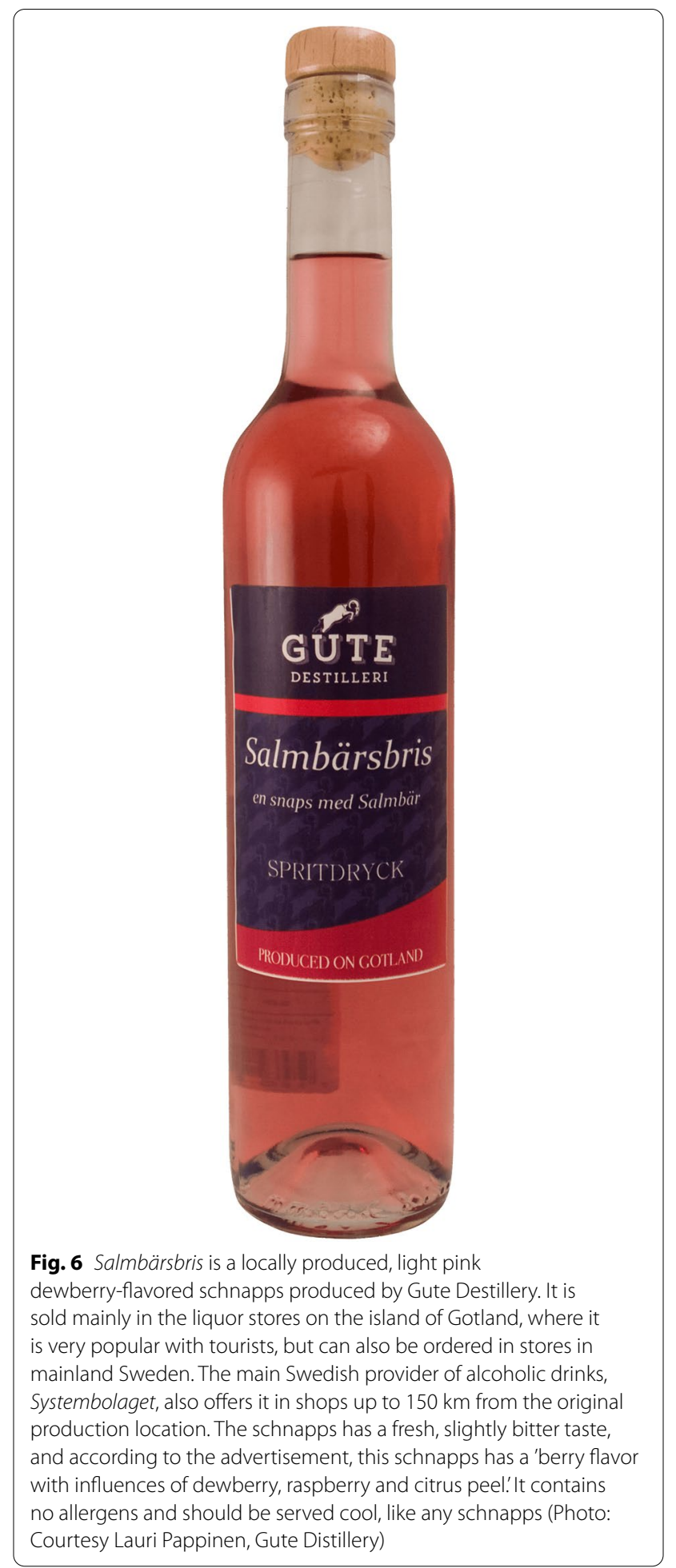

\section{Comparison with other local products}

Gotland has recently started to promote several locally produced dishes in addition to dewberry jam and saffron pancake, including some including wild-harvested 
products. A comparison with the other plants harvested in Gotland shows that dewberry products are far more famous and popular than the other more recently introduced ones.

The most successful newcomer is Burgundy truffle, Tuber uncinatum Chatin. The species was first found in Gotland in 1977 and has since then been discovered in several locations on the island. In 2012, nearly $700 \mathrm{~kg}$ of wild truffle was gathered. When the truffle is ready for harvest, it emits a very distinct scent, allowing dogs with their keen sense of smell to find them. In 2014, around ten commercial producers of truffle were active in Gotland $[58,63]$.

Ramson, Allium ursinum L., is a wild garlic mentioned by Linnaeus already in 1741. In 2014, there was one local company for ramson products $[3,58]$. Traditionally, this garlic has been harvested by Gotland inhabitants for seasoning hotpots and vegetable stews. It is still used and sold as a vegetable, but it has also been developed to suit modern tastes, and is now used among others in pesto and vinegar [64].

Sand onion, Allium scorodoprasum L., locally known as kajp, is a wild onion with a flavor reminding of leek, but with a stronger taste. It is an ingredient in the local Gotland dish kajpsoppa 'sand onion soup.' In 2014, one producer was actively using it. Sand onion is only harvested and used on the island and nowhere else in Sweden [58, 66].

\section{Discussion}

Wild plants must be common in order to become food plants [8]. The dewberry bush benefits from a calcareous soil, hence its abundant occurrence in Gotland. Outside the island, dewberry is too scarce to be harvested for the food industry in Sweden. Nowadays, it is possible to buy dewberry jam not only in tourist shops in Gotland, but also in gourmet stores on the Swedish mainland. Vendors at weekly and seasonal markets throughout Sweden, specializing in wild berry products, frequently offer jars with dewberry jam from Gotland. Shops offering local food products from all over the country provide dewberry products, too, despite some resistance against the national distribution among producers in Gotland (Fig. 7).

The dewberry is nowadays considered a regional Gotland specialty and has become a terroir, part of the local character, embodying certain qualities of the island and symbolizing its food culture. The concept terroir includes in this context everything the earth gives, from the influence on the taste to the cultural-historical context forming the final product $[55,60,67]$. Also the story behind the dewberry, gathering and picking, the local habitat, its connections, and last but not least, the creative process

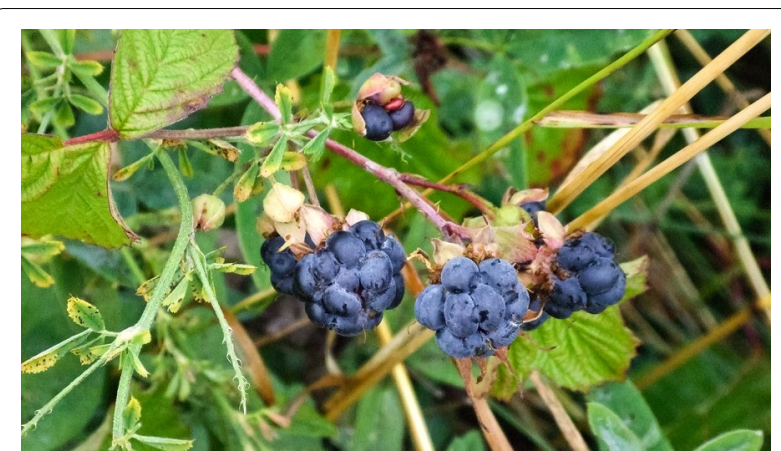

Fig. 7 Delicious dewberries, locally known as salmbär, are common all over the island of Gotland, but grow mainly in the southwestern part, and less in the eastern and northern parts, which are more open to the winds from the Baltic Sea. The berries ripe in July to August. They must be gathered only when completely mature to give the specific taste to the jam; otherwise, the jam will be too sour. Much sugar is needed to cover the acid taste of the berries, but children like to eat the berries also fresh. These berries were photographed in July 2008 by a road in Vibble, Gotland, Sweden (Photo: W. Carter, Creative Commons)

in preparing the food are important and contribute to the added value, which is being constructed around the food product. Many foreign tourists in Gotland are curious of the dewberries, of which they do not have previous experience, and they often ask the tourist information bureau and tourist guides about the berries, and what they are called in English, German, Italian, Spanish, etc. [55, 68].

\section{The role of New Nordic Cuisine}

The increasing popularity of the dewberry among contemporary Swedish chefs is reflected in the frequent use for exclusive meals in various contexts. At the Nobel Prize celebration banquet in Stockholm in December 2014, a mousse and sorbet made of wild dewberries from Gotland were served with saffron pancake (re-baptized, probably for the international guests, as panna cotta) and a cake with a classical French sauce. The menu offered contained Mousse et sorbet de baies bleues de ronces sauvages de Gotland panna cotta au safran et génoise au beurre noisette 'Mousse and sorbet of wild dewberries from Gotland, saffron panna cotta and brown [hazelnut] butter sponge cake' [69]. After this famous event, dewberry products became hugely popular nationwide, with some reverberations internationally among some chefs, and it is no longer only a regional specialty, but an integral part of Swedish haute cuisine [70]. Dewberry can now be considered to be a classic example of the New Nordic Cuisine, which focuses on local, preferably wild products, and raises them from anonymity to publicity and popularity. The success of dewberry products in Sweden has inspired also food craft artisans in 
the Swedish-speaking Åland Islands, but so far no bigger market has developed in Finland [71].

\section{Popularity of edible berries}

Edible forest berries are an increasingly important cultural ecosystem service not only in Sweden, but all over Europe [72]. In present-day Swedish cuisine, a wide variety of berry species play an important role. Many Swedes see berries as nutraceuticals for health improvement [65]. Yet only when sugar by the end of the nineteenth century became cheaper and a commonly accessible commodity for peasants, small-scale farmers, and working classes, wild berries were gathered in larger quantities in Sweden. Several forest fruits were suddenly popular, and they are nowadays considered important traditional ingredients in the Swedish food culture. Dewberry, however, had to wait a few decades more for popularity. A comparison with some other berries shows that the rise of the dewberry is a present-day phenomenon, which differs somewhat from the interest in other berries. A possible reason is that the other berries grow in vast areas on the mainland, but the dewberry is mainly available locally.

Cowberry, for instance, is used in lots of dishes nowadays. Cowberries, Vaccinium vitis-idaea L., and cloudberries, Rubus chamaemorus L., were used as food and probably as a source of vitamins for the rural poor in the northern part of the country. In the south, berries did not belong to the menu, although it was possible to preserve these two berries without sugar [3, 73, 74]. Finnish-speakers living in the central part of Sweden utilized large quantities of cowberries for jam, Finnish hillo [75]. Fresh bilberries, Vaccinium myrtillus L., were eaten with milk or cream, but otherwise they were mostly consumed fresh by children [76], similar to wild raspberry, Rubus idaeus L. [3, 13].

Large amounts of wild forest berries are consumed yearly in Sweden, and the trend is growing; consumption increased from $16.4 \mathrm{~kg}$ in 2000 to 34.4 million kilograms in 2017 [77]. For the food industry, unskilled seasonal workers are imported as berry pickers every summer, for instance, from Bulgaria, Poland, Ukraine, Thailand, and Cambodia $[78,79]$.

\section{The wild pantry and food stories}

Food and culture researcher Håkan Jönsson explains that the wild pantry has 'many shelves.' One is about upgrading gastronomy and creating fresh interest in the taste quality of a specific location. Another is the commercialization of resources regulated by law. A third shelf tells how the relationship between humans and nature has become an important trigger for new and fashionable 'traditional' activities. Nature has become part of the experience economy, and while tourists seek different kinds of experiences, they create new frameworks for meanings in our relation to nature [22].

Historian Michael Schoultz notes that in the regional identity creation process, image construction, and branding of Gotland, the tourist business plays an important role. Looking for special characteristics, it finds specifics also in the food. Researcher Hanne Pico Larsen adds a further aspect: in addition to the terroir stories, the experience, and interpretation of the food, the story of a product is based also on the stories served before, during and after consumption. These stories bring the consumer out into nature, the harvesting, producing and other processes. When the consumer returns from the culinary journey, an extra layer is added to the story when it is told to others. In her view, the success of the New Nordic Cuisine originates in the way consumers have been convinced to listen to these descriptions; the reactions are mostly enthusiastic. Several Nordic chefs are especially talented in telling stories the tourists and culinary travelers want to hear and offering them a hands-on philosophy based on the use of local, 'real' and 'clean' food ingredients, unique tastes and qualities, and traditional ways of gathering and preparation $[55,60,80]$.

\section{Creating images}

Local food plays an important role in different processes of image creation, but it has a crucial significance for the local economy in tourist destinations, too. The unique taste and flavor of the dewberries are important in this process, and also the creative chefs and innovative food creators, and the fact that the dewberry grows mainly in Gotland and is not generally available elsewhere in Sweden play a role. The soil and climate of the island are generous for the growth of dewberry bushes, and although dewberry grows also along the southern coastline, the occurrence is not concentrated and large enough for food industry purposes. Bilberry and cowberry, for example, grow in vast areas on the mainland but little in Gotland, which make them a rarity on the island. This limited availability adds to the intricate stories Hanne Pico Larsen sees as a multiple-layer narrative: from the gathering to a life of the stories long after consumption; dozens or hundreds of people are telling and adding to the story of the dewberry, until it becomes far more than just a simple berry $[60,81,82]$ (Fig. 8).

\section{Conclusion}

Modern society is urban, globalized, and information, saturated, and ideas, fashions, and goods are quickly brought to national and international markets. The physical environment is changing, and local knowledge and traditions are substituted not so much by global, but glocal (simultaneously global and local) habits. Local or 


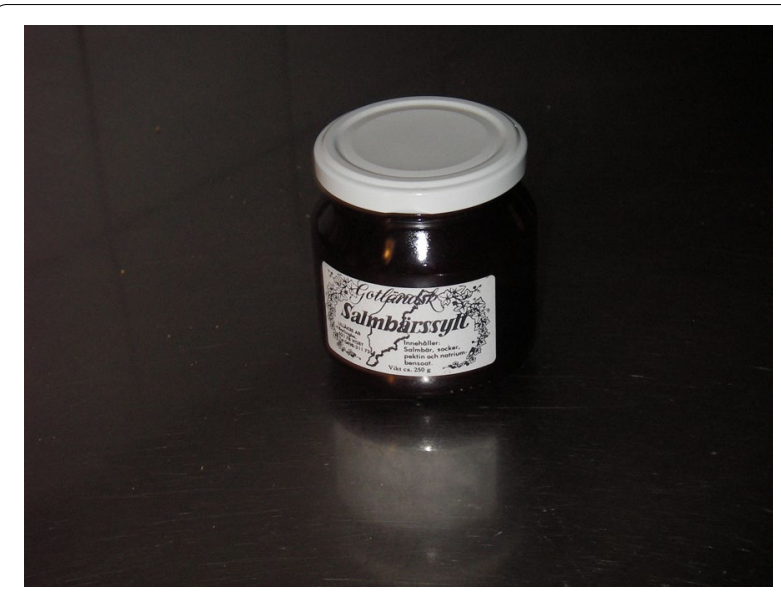

Fig. 8 A jar of dewberry jam manufactured by a Gotland company. Currently there are several small, local factories producing dewberry jam, which is mainly sold to tourists and served in restaurants on the island together with saffron pancake. An increasing amount is also brought to the Swedish mainland and sold in delicatessen stores, shops specialized in food from all over the country, and in the weekly or seasonal markets in Sweden (Photo: Ingvar Svanberg, 2008) regional food and ingredients can be brought in from the margins of geography to national and global consciousness and plates within a very short time span, and they might become part of a globalized foodscape within just a few decades or even years. Often TV and internet are the means for transmitting culinary news, and traveling chef shows focus with gusto on local dishes or ingredients.

The never-ending search for exotic, exciting and special foods, and ingredients has moved from regional and national to a global internet-based community, consisting of hungry for new experiences consumers, whose interests also the tourist businesses increasingly strive to satisfy. When an ingredient, plant, or dish becomes mainstream, the most seasoned and innovation-minded gastrotourists usually move on to something else, leaving the ingredient or dish behind and looking for something more exciting, rare, dangerous, generally unknown, or connected to a specific location, which is maybe only now opening up to the world. This process happens with increasing velocity.

The Gotland dewberry seems to run no risk, however, of being set aside in the future, for several reasons. Saffron pancake served with dewberry jam is a well-known tourist symbol for the island and will probably remain a local specialty as long as visitors see Gotland as an enjoyable summer destination. The Gutnish name salmbär has been recognized as the name of the product and berry in Sweden, and although dewberry jam is available also on the mainland, it is still considered a rarity, and therefore, it remains a highly coveted product. The production of wild berries in the specific landscape is and will always remain limited, due to the island character of the area.

Dewberry also grows elsewhere in Europe, and in Central Asia. These areas could, if dewberry at some point in the future becomes a global delicacy, turn into a major competition to the small-scale Gotland producers. So far the berry does not seem to have gained larger global attention outside Scandinavia and Northern Europe, despite its fame during the Nobel Prize celebration in 2014, and some Swedish chefs' and a few other efforts to include it in innovative dishes since then. The dewberry appears to be a wild berry with potential, but whether it will undertake a further journey from national to global, similar to the ascent from regional to national, only the future will show.

\section{Acknowledgements}

Thanks to Lauri Pappinen, Näsudden, for providing a photograph of Salmbärsbris.

\section{Authors' contributions}

This study was designed by IS, and both authors collected the data during the studies. Both authors read and approved the final manuscript.

\section{Availability of data and materials}

All data generated or analyzed during this study are included in the article.

\section{Declarations}

Ethics approval and consent to participate

This kind of research did not need approval from the ethics committees in our faculties.

\section{Consent for publication}

All data were published under previous consent of participants.

\section{Competing interests}

The authors declare that they have no competing interests.

Received: 8 March 2021 Accepted: 18 November 2021

Published online: 29 November 2021

\section{References}

1. Millennium ecosystem assessment ecosystems and human well-being. synthesis. Washington: Island Press; 2005.

2. Svanberg I, Lindh H. Mushroom hunting and consumption in twenty-first century post-industrial Sweden. J Ethnobiol Ethnomed. 2019;15(42):1-23. https://doi.org/10.1186/s13002-019-0318-z.

3. Svanberg I. The use of wild plants as food in pre-industrial Sweden. Acta Soc Bot Pol. 2012;81:317-27. https://doi.org/10.5586/asbp.2012.039.

4. Fredman P, Stenseke M, Sandell K, Mossing A. Friluftsliv i förändring. Resultat från ett forskningsprogram. Slutrapport. Naturvårdsverket Rapport 6547. Stockholm; 2013.

5. Nolan JM. Wild harvest in the Heartland: ethnobotany in Missouri's Little Dixie. Lahnam: University Press of America; 2007.

6. Svanberg I, Łuczaj Ł, Activity contexts and biocultural domains. In: Pioneers in European Ethnobiology. Svanberg, I. \& Ł. Łuczaj, editors. Uppsala: Centre for Russian Studies; 2014. p. 9-26.

7. Ljung PE, Sandström C, Ericsson G, Kvastegård E. Konsumtion av skogens ekosystemtjänster - vilt, svamp och bär. Umeå: SLU; 2014.

8. Łuczaj Ł, Pieroni A, Tardío J, Pardo-de-Santayana M, Sõukand R, Svanberg I, Kalle R. Wild food plant use in 21st century Europe, the disappearance of old traditions and the search for new cuisines involving wild edibles. 
Acta Soc Bot Pol. 2012;81 (4):359-70. https://doi.org/10.5586/asbp.2012. 031.

9. Erixon S. Surviving primitive gathering in the Nordic countries. Folk-Liv: Acta ethnologica Europaea; 1951;14-15:95-102.

10. Fjellström P. Nord- och mellansvenskt kosthåll i kulturekologisk belysning. In: Mat och Miljö: En bok om svenska kostvanor. N-A. Bringéus, editors. Lund: Gleerups; 1970. p. 41-64.

11. Bringéus N-A. Matkulturen i jämförande perspektiv i 1700-talets Norrland. In: "Maten er meir enn føda": Rapport fra et seminar om mattradisjoner Arendal, 25-26. Okt. 1996. Bø, S. \& G. Norby, editors. Trondheim: Landslaget for lokalhistorie; 1998.

12. Bringéus N-A. Man, food and milieu: a Swedish approach to food ethnology. East Lothian: Tuckwell Press; 2001.

13. Svanberg I. Folklig flora. Stockholm: Dialogos; 2011.

14. Martinsson K, Ryman S-G. Blomboken: bilder ur Olof Rudbecks stora botaniska verk. Stockholm: Prisma; 2008.

15. Fischerström J. Nya swenska economiska dictionnairen, eller Försök til ett allmänt och fullständigt lexikon i swenska hushållningen och naturlära 4. Stockholm: Carl Stolpe; 1792.

16. Quensel C, Palmstruch JW. Svensk botanik 4. Stockholm: Carl Delén; 1805.

17. Armfelt Hansell Ö. Bärboken. Stockholm: P.A. Norstedt; 1969.

18. Wallace J-E. Blåhallon (Rubus caesius L.). Veckans växt v. 35, 2008. SLU Alnarp; 2008. https://www.slu.se/globalassets/ew/org/centrb/pom/blaha Ilon.pdf. Retrieved 160June 2021.

19. The New Nordic Cuisine. Copenhagen: Nordic Council of Ministers; 2008.

20. Gyimóthi S. The reinvention of terroir in Danish food place promotion. Eur Plan Stud. 2017;25(7):1200-16. https://doi.org/10.1080/09654313.2017. 1281229.

21. Stryamets N, Elbakidze M, Ceuterick M, Angelstam P, Axelsson R. From economic survival to recreation: contemporary uses of wild food and medicine in rural Sweden, Ukraine and NW Russia. J Ethnobiol Ethnomed. 2015;11(53):1-18. https://doi.org/10.1186/s13002-015-0036-0.

22. Jönsson H. Den ätbara naturen. In: Naturen för mig: nutida roster och kulturella perspektiv. Midholm, L. \& K. Saltzman, editors. Göteborg: Institutet för språk och folkminnen; 2014. p. 331-38.

23. Mossberg B, Stenberg L. Nordens flora. Stockholm; Bonnier Fakta; 2018.

24. Oredsson A. Frequency pattern of Rubus caesius L. on Gotland, Sweden. Sven. Bot. Tidskr. 1975;69:188-90.

25. Hultén E, Fries M. Atlas of North European Vascular Plants: north of the tropic of cancer. Königstein: Koeltz Scientific Books; 1986.

26. Franckenius J. Speculum botanicum. Upsalæ: J. Pauli; 1659.

27. Gustavson H. Gotländska ortnamn. Ortnamnssällskapets i Uppsala: Årsskrift 1938;3:3-58.

28. Swedish Institute of language and folklore, Uppsala: ULMA 18907 (Atlingbo, Gotl.); ULMA 18908 (Hemse, Gotl.); ULMA 20254 (Vamlingbo, Gotl.); ULMA 20438 (När, Gotl.).

29. Larsson S. Gotländska växtnamn. Från Gutabygd. 1980;2:38-53.

30. Gustavson H. Gotländsk ordbok på grund av C. och P.A. Säves samlingar, vol. 2. Uppsala: Landsmålsarkivet; 1945.

31. Gustavson H. Gotländska växtnamn. Visby: Allehandas Tryckeri; 1947.

32. Ekvall U. Gotländska växtnamn: tradition och förnyelse i ett lokalt växtnamnsskick. Stockholm: Almqvist \& Wiksell International; 1990.

33. Stobaeus P. Satyrion och sömntorn. Yearbook of the Swedish Linnaeus Society; 2002-2003:69-98.

34. Klintberg M, Gustavson H. Ordbok över Laumålet på Gotland 3. Uppsala: AB Lundequistska; 1979.

35. Hjelmqvist T. Bibliska personers namn med sekundär användning i nysvenskan: samlingar och studier. Lund: C.W.K. Gleerup; 1901.

36. Linnaeus C. Flora suecica: Enumerans Plantas Sueciae Indigenas Cum Synopsi Classium Ordinumque, Characteribus Generum, Differentiis Specierum, Synonymis Citationibusque Selectis. Stockholm: Salvius; 1755

37. Vesterlund O. Växtnamn på folkspråket. Bot Not. 1893:133-135.

38. Westerlund CG. Växtnamn på folkspråket i Lena socken i Uppland. Bot Not. 1903:99-101

39. Vide S-B. Sydsvenska växtnamn. Lund: Gleerup; 1966.

40. Liro Jl. Åländska växtnamn. Helsingfors: Societatis pro fauna et flora fennica; 1915.

41. Olsson PH. Svenska växtnamn i sydvästra Finland. Bot Not. 1896;59:1-10

42. Suhonen P. Suomalaiset kasvinnimet [Finnish plant-names]. Helsinki: Societatis Zoologicæ-Botanicæ Fennicæ. Vanamo; 1936.
43. Tiberg N. Dagösvenskarna: några orienterande anteckningar. Sven landsmål Sven folkliv. 1925;169:5-16.

44. Tiberg N. Runöbornas ägor. Uppsala: Lundequistska; 1959.

45. Pettersson B. Antonius Münchenbergs herbarium vivum. Bot Not. 1948:2:223-69.

46. Paulli S. Flora Danica det er: Dansk Urtebog: Udi huilcken, efter hans Kongl: Mayst... Christiani IV... skriftlig Befalning til Facultatem Medicam, udi det Kongelig Universiteet Kiøbenhafn, icke alleeniste Urternis Historiske Beskrifvelse, Krafters oc Virkninger, med zijrligste Figurer andragis: Men endocsaa Lægedomme til alle Siugdomme gafulige, korteligen oc klarligen antegnis: Saa at den er baade en Urtebog oc Lægebog. Kiøbenhafn: Melchior Maltzan; 1648.

47. Moseley C, editor. Atlas of the world's languages in danger. Memory of peoples (3rd ed.). Paris: UNESCO Publishing; 2010.

48. Linnaeus C. Öländska och Gothländska Resa förrättad år 1741. Stockholm: Gottfried Kiesewetter; 1745.

49. Swedish Institute of language and folklore, Uppsala: folklore record ULMA 19160 (Garda, Gotl.).

50. Svanberg I. Blåhallon, Rubus caesius. In: Människan och floran: etnobiologi i Sverige vol. 2. Iwarsson, M. \& B. Pettersson \& H. Tunón, editors. Stockholm: Wahlström \& Widstrand; 2005, p. 259.

51. Swedish Institute of language and folklore, Uppsala: ULMA 20452, ULMA 27697.

52. Lingegård I. Gotländska mattraditioner: seder och bruk i helg och vardag. Stockholm: LT; 1978.

53. Genrup K. Mat och måltidsseder på Gotland. Visby: Guteböcker; 1992.

54. Swedish Institute of language and folklore. Uppsala: folklore record ULMA 27697 (Fide parish, Gotland).

55. Ronström O. Saffron pancake with dewberry jam and whipped cream. In: A taste of Islands: 60 recipes and stories from our world of Islands. Baldacchino, A. \& G. Baldacchino, editors. Charlottetown, PE: Island Studies Press. p. 252-55.

56. https://bakfickan-visby.nu/gotlandsk-saffranspannkaka/; https://recep tfavoriter.se/recept/gotlandspannkaka.html; https://ylvasbakverkstad. com/gotlandsk-saffranspannkaka/; http://husprojektet.bloggplatsen.se/ 2011/08/09/5994151-baka-gotlands-basta-saffranspannkaka/; https:// sotasaker.com/2016/09/02/gotlandsk-saffranspannkaka/. Retrieved 24 Feb 2021.

57. Jutehammar A. Sveriges Radio: Kaliber: Salmbärskvinnorna. 12 October 2015. https://sverigesradio.se/avsnitt/617521. Retrieved 16 June 2021.

58. Duong TNP. Food tourism for regional sustainable development: challenges in collaborations for local restaurants on Gotland. Uppsala University: Disciplinary Domain of Science and Technology, Technology, Department of Civil and Industrial Engineering; 2020.

59. Sörensson A. sustainable tourism at mass tourist destinations: best practice from tourist producers in Europe. WIT Trans Ecol Environ. 2010;142:593-604. https://doi.org/10.2495/SW100541.

60. Pico LH, Österlund-Potzsch S. Islands in the Sun: storytelling, place \& terroir in food production on Nordic islands. Ethnol Scand. 2015;45:29-52.

61. Svanberg I. The importance of animal and marine fat in the faroese cuisine: the past, present and future of local food knowledge in an Island Society. Front Sustain Food Syst. 2021: 1-18. https://doi.org/10.3389/fsufs. 2021.599476.

62. Hammar I. En bakelse som heter Polhelm. Helagotland.se 28 Febr. 2008. https://helagotland.se/nyheter. Retrived 24 Feb 2021.

63. Wedén C. Tryffel - mat för gudar, gutar och svin. Stockholm: Infotain Infobooks Sweden; 2008.

64. Sundgren L, Kalfhansen R. Det vilda köket. Stockholm: Bonnier Fakta; 2016.

65. Svanberg I. Jätteslide och rönnbärsbitter - postmodern etnobiologi om konst, matglädje och prepping. Sven Bot Tidskr. 2017;111(1):20-45.

66. Genrup K. Kajp. In: Människan och floran: etnobiologi i Sverige vol. 2. Iwarsson, M. \& B. Pettersson \& H. Tunón, editors. Stockholm: Wahlström \& Widstrand, 2005. p. 271.

67. Nygård O, Wramner P. Terroir-a key concept when building a geographic identity for food. In: Food and rurality in Europe: Economy, environment and institutions in contemporary rural Europe. Rytkönen, P., editor. Huddinge: Södertörns högskola, Sweden; 2014. p. 311-64.

68. Hermansen, ME. Creating terroir: an anthropological perspective on new Nordic cuisine as an expression of Nordic identity. Anthropology of Food S7; 2012. https://doi.org/10.4000/aof.7249. 
69. Nobel Banquet Menu 2014. NobelPrize.org. Nobel Media AB 2021. Wed. 24 Feb 2021. https://www.nobelprize.org/ceremonies/nobel-banquetmenu-2014. Retrieved 24 Feb 2021.

70. Larsson U. Nobellbankettens menyer: svenskt, sensoriskt och metodiskt. Idun. 2018:23:105-13.

71. https://svenska.yle.fi/artikel/2012/10/15/goda-blommor-och-bar. Retrieved 24 Feb 2021.

72. Schulp CJE, Thuiller E, Verburg PH. Wild food in Europe: a synthesis of knowledge and data of terrestrial wild food as an ecosystem service. Ecol Econ. 2014;105:292-305.

73. Bringéus NA. The red gold of the forest. In: Food from Nature: Attitudes, Strategies and Culinary Practices. Lysaght, P. editor. Uppsala: The Royal Gustavus Adolphus Academy for Swedish Folk Culture; 2000. p. 225-39.

74. Eidlitz K. Food and emergency food in the circumpolar area. Almqvist \& Wiksell International: Uppsala; 1969.

75. Sapponen E. Värmlannin metsäsuomalaiset: Asutushistoriasta, agraarista kulttuurista ja muutoksesta [Värmland Forest Finns: Settlement history, agrarian culture and changes].Turku: Siirtolaisuus-Instituutti; 2019.

76. Klintberg B. Blåbär Gastronomisk kalender. Stockholm. 1999;39:60-72.

77. Sveriges Officiella Statistik. Statistiska Meddelanden JO 44 SM 1801. Food consumption and nutritive values, data up to 2017. Stockholm: Jordbruksverket; 2018
78. Hedberg C. 'Doing gender' in the wild berry industry: transforming the role of Thai women in rural Sweden 1980-2012. Eur J Women's Stud. 2016;23(2):169-84. https://doi.org/10.1177/1350506815571143.

79. Hedberg C. 'Grapes of Wrath'. Power spatialities and aspects of labour in the wild berry global commodity chain. Compet Change. 2013;17(1): 57-74. https://doi.org/10.1179/1024529412Z.00000000025.

80. Scholz MF. Regional identitet som politisk fråga - Gotlandsturism och varumärkesutveckling fram till andra världskriget. In: Kolbe W, editor. Turismhistoria i Norden. Uppsala: Kungliga Gustav Adolfs Akademien; 2018. p. 143-56.

81. Tellström R, Gustafsson I-B, Mossberg L. Consuming heritage: the use of local food cultures in branding. Place Brand. 2006;2:130-43.

82. Tellström R, Gustafsson I-B, Mossberg L. Local food cultures in the rural regional economy. Soc Rural. 2005;45(4):346-59.

\section{Publisher's Note}

Springer Nature remains neutral with regard to jurisdictional claims in published maps and institutional affiliations.
Ready to submit your research? Choose BMC and benefit from:

- fast, convenient online submission

- thorough peer review by experienced researchers in your field

- rapid publication on acceptance

- support for research data, including large and complex data types

- gold Open Access which fosters wider collaboration and increased citations

- maximum visibility for your research: over $100 \mathrm{M}$ website views per year

At BMC, research is always in progress.

Learn more biomedcentral.com/submissions 